\title{
SUBSTANTIATION OF THEORETICAL FUNDAMENTALS OF SOCIAL CONTROL IN THE SPHERE OF ECONOMIC MANAGEMENT
}

\author{
Sergiy Bardash ${ }^{1}$, Tatiana Osadcha $^{2}$
}

\begin{abstract}
Urgency of the research is due to the fact that social control is an integral and comprehensive component of any society. The development of theoretical, methodological and practical foundations of social control and the application of its cognitive tools in the transformation of consciousness and participation in the development of a democratic society on the basis of sustainability is of paramount importance. The research activity of scientists in studying philosophical, social, legal, economic, educational and other aspects of control as a complex polymorphic phenomenon is due to the fact that social relations are certainly an important component of the economy at all levels. However, the social mechanism for regulating economic systems at various levels remains ineffective. The purpose and the objective of the research are to prove the importance of social control in the sphere of economic management and to determine its theoretical foundations. The research methodology consists in the dialectical method of understanding the essence of social control and assessing its importance in the sphere of economic management; general scientific methods of analysis, abstraction, induction and deduction, synthesis and generalization are used to substantiate the basic theoretical provisions, the formation of the conceptual framework of social control in the sphere of economic management, the formulation of conclusions. The most significant scientific results are as follows: proving the importance of public control in the sphere of economic management, recognizing it as an indispensable element of the social mechanism for the development of economic systems at all levels of the economy; defining its theoretical foundations: the scope of application, object, matter, subject, forms and results. The practical significance of the research is to determine the vector of control development in the sphere of economic management - compliance with standards that affect the economic interest and determine economic behaviour. Value/originality. The results obtained can be considered as forming the concept of behavioural control in the sphere of economic management and create new grounds for developing the theory and practice of social audit as well as reviewing the paradigm of economic management control.
\end{abstract}

Key words: social control in the sphere of economic management, social audit, social and economic relations, economic interest, economic behaviour.

JEL Classification: M10, M40

\section{Introduction}

The rapid development of civilization convincingly proves that the importance of social control is not lost, but only gaining weight. A more or less stable interpretation of social control as a way of selfregulation of the social system, which ensures the orderliness of interactions between individuals through regulation is gradually transformed due to the shift of emphasis from the economic component to the social. The world's leading economists are beginning to realize that economic development can occur mainly in harmoniously developed social systems. At present, everyone agrees that social control guarantees comfortable behavior of members of society or social group in relation to role requirements and expectations, including those determined by the content of economic relations. Social control is one of the basic concepts in sociology. They denote

\footnotetext{
Corresponding author:

${ }^{1}$ National University of Life and Environmental Sciences of Ukraine, Ukraine.

E-mail: serg.bardash@gmail.com

ORCID: https://orcid.org/0000-0001-5711-5229

ResearcherID: F-4116-2018

${ }^{2}$ Kherson State University, Ukraine.

E-mail: tatiana@osadcha.com

ORCID: https://orcid.org/0000-0003-4258-0907

ResearcherID: F-4110-2018
} 
the various means that any society uses to tame its rebellious members. No society can do without social control. Such control is extremely necessary even for a small social group that was formed accidentally or deliberately to achieve a common goal, as well as the subjective goals of its individual members. Without certain norms of behavior and the mechanism of their control, the life cycle of such a group will be short.

The most important recent events, including global economic processes, the development of artificial intelligence, the digitalization of economic relations, the impact of the COVID-19 pandemic on the socioeconomic development of many cranes in the world, are still factors that force to reconsider the importance and prospects of social control development.

Social control is an integral and comprehensive part of any society. Scientific research into the nature, content and forms of social control is becoming increasingly important. Researchers emphasise the legal, economic, sociological and ethical aspects of studying control as a social phenomenon. Such activity of scientists is due to the fact that social relations are a key component of the economy at all levels. The individual, who is an element of society, realizes economic relations, and his or her activities in the field of economic management are one of the conditions for the growth of the national economy. However, the social mechanism for regulating economic systems at various levels remains ineffective. Research into the philosophical foundations of social control in the field of economic management as an element of this mechanism is therefore relevant.

\section{Overview of the polymorphic nature of social control}

The problem of social control has been studied by all sociology theorists, starting with O. Conte, G. Spencer and J. Spencer, J-G. Tarde, E. Durkheim, P. Sorokin, T. Parsons, R. Merton, N. Luman, J. Gilinsky and others.

The foundations for the study of the diversity of social control manifestations are laid down in the works of E. Ross (Ross, 1969), M. Janowitz (Janowitz, 1975), R. Meier (Meier, 1982), S. Sumner (Sumner, 1994), R. Akers (Akers, 2012) and other foreign scientists.

The importance of social control in the assessment of civilization transformations has been convincingly proven by the fact that its essence, meaning, functions and forms are examined from the standpoint of philosophy, law, pedagogy, sociology, and criminology.

Recently, the results of studies of the importance and impact of social control, in particular, social audit, on economic relations have been presented in the publications of H.M. Boislandelle, J-M. Esteve (Boislandelle, Esteve, 2007), G. Lehman (Lehman, 2006), H. Ahaverdiieva, O. Ivanisova, O. Lebedynska (Ahaverdiieva, Ivanisov, Lebedynska, 2019), F. Aliieva (Aliieva, 2008), L. Holinach (Holinach, 2015), V. Derii,
S. Sachenko, L. Babii (Derii, Sachenko, Babii, 2016), V. Yemelina, Y. Skvortsova (Yemelin, Skvortsova, 2013), D. Dolbnieva (Dolbnieva, 2014), V. Levitskyi (Levytskyi, 2012), O. Mazuryk (Mazuryk, 2011, 2014) and others.

While recognising the significant contribution to the development of theoretical and methodological aspects of social audit as a tool for measuring the level of social responsibility of economic entities, it should be noted that the importance of social control over economic relations and the definition of its theoretical foundations remain under development.

The philosophical foundations of social control in the field of economic management are, firstly, a metaconstruction of its basic provisions as a field of scientificknowledge, and secondly, a system of categorical meanings. Their substantiation will make it possible to establish the relationship between scientific knowledge and worldview benchmarks that have developed within a certain socio-cultural space regarding social control. These foundations include philosophical approaches to understanding the concepts of the essence, subject, object, matter and form.

Today we can distinguish three groups of approaches to the essence and content of social control. According to the first approach, social control is seen as the influence of large social groups, including the state, on the goals, actions, behaviour of the individual.

Sociological interpretations of social control include both regulation of individual behaviour through the internalisation of social norms and regulation of behaviour through outside or external social sanctions (Mazuryk, 2011). At the same time, approaches to understanding social control differ, which explains the new attempts by sociologists working in competing paradigms to clarify this concept.

The second approach is based on the consideration of social control as a set of norms, institutions and relations aimed at ensuring the behaviour of people in accordance with those norms that are protected by society, state, social groups and express their interests, as well as a tool to identify and study the causes of delinquent behaviour (Bardash, 2013).

Proponents of the third approach consider social control as a subsystem for managing the social and economic sustainability of the enterprise (Aliyev, 2008).

In characterising the above approaches from the standpoint of the purpose of the study, it is worth noting that, in our opinion, there are some shortcomings. Firstly, researchers studying the sociological aspect of social control do not disclose its procedural component, how it should be implemented, in particular it is noted that social control refers to the practice of all types of social groups with the prescription and encouragement of conformity and the application of sanctions to behaviour, which violates the established norms (Berger, 2004). According to S. Spilnyk, "in general, social 
control is one of the most important functions of public administration, which makes it possible to identify and prevent deviations, errors and shortcomings that arise in the social organisation of society". Thus, such control can be recognized as state social control, the only form of which, according to S. Spilnyk, is supervision (Spilnyk, 2012).

Secondly, the legal approach also has similar shortcomings, as social control is positioned by its supporters at the state level and identified as formal. The entities of such control include supervisory authorities, respectively, supervision is considered to be the only form. The emphasis in the legal approach is on the tools of social control (punishment) and their impact on the behaviour of individuals.

Thirdly, in studies that reveal the economic aspect, social control is defined as one of the main components of enterprise development as a holistic socio-economic structure. The forms of such control at the enterprise are inventory and audit of the actual state of affairs in the social sphere of the enterprise and verification of compliance of this state with mandatory standards established by the state, the enterprise itself or verification of social reporting (Levytskyi, 2012). Thus, the forms of social control, according to this approach, are inventory and audit, the content of which does not correspond to the long-held beliefs of economic control specialists. Even if we agree on the forms of such controls, then methodological methods, standards and factual information must be defined for their implementation in practice in order to comply with the principle of comparability.

O. Mazuryk's research should be singled out, within which the author seeks to conceptualize social audit and outline its theoretical and methodological foundations in the sociological tradition of studying social control. He notes: "Social audit is a way to comprehensively and objectively assess the state of social relations at various levels (corporate, municipal, industrial, regional, national), which makes it possible to identify potential threats of deterioration of the social climate, reserves of human resources development, etc.” (Mazuryk, 2011).

It should be noted that a large number of domestic and foreign scientists, in particular K. Abdurakhmanov, A. Andriushchenko, B. Bondarets, M. Bukovynska, R. Vatye, O. Hnatiuk, A. Danyliuk, T. Kalinescu, A. Kasperovych, N. Marushko, S. Poliakova, H. Potopalska, Yu. Popov, A. Svyrydov, A. Sotula, V. Ter-Akopyan, P. Schlender, O. Shulus and others, have been and continue to be actively involved in shaping the theoretical and methodological foundations of social audits.

Currently, some researchers note that social audit is: - a specific form of analysis, revision of the social environment of the enterprise to identify social risk factors and implement proposals to reduce them in the result of the development of other forms of audits, in particular, management and financial audits by expanding the performance criteria, as they include many social factors (Mekheda, Madzhula, 2010);

- an instrument for regulating social and economic relations through voluntary social dialogue of all parties interested in achieving social consensus (Marushko, Volianyk, 2013);

- one of the main and most realistic directions of increasing the competitiveness of domestic enterprises, as it allows all interested parties to receive complete and objective information about the state of the social and labour sphere at the enterprise, implementation of the enterprise's plans on social, economic and environmental measures; strengthens public control over compliance with certain standards and norms at the enterprise (Dolbnieva, 2014);

- a tool for assessing, monitoring and controlling social and economic relations, the purpose of which is to identify social risk factors and development reserves of human resource in order to ensure a favourable social climate for the economic entity and to improve the effectiveness of its quality management system (Chenash, 2016);

- an operational assistance for management personnel to ensure the effective implementation of social policy, and later it is a method of confirming the level of corporate social responsibility (Derii, Sachenko, Babii, 2016);

- a universal technology for comprehensive verification of the actual state of a social object in relation to the accepted standards, ... the complexity of social audit consists in the systematic application of various research procedures: software audit, monitoring, diagnostics, social expertise, qualimetric analysis, survey, document analysis, etc. (Mazuryk, 2015).

Thus, according to the authors of some publications, social audit is: a specific form of analysis, audit, ... the result of the development of other forms of audit; a tool for regulating social and economic relations; one of the main and most realistic directions of competitiveness improvement; a tool for assessment, monitoring and control ...; an operational assistance for management personnel and a method for confirming the level of corporate social responsibility; a universal technology for comprehensive verification of the actual state of a social object in relation to the accepted standards.

This polymorphism of views on the nature and significance of social audit is explained by the fact that, as noted by O. Mazuryk, "To date, the development of social audit is carried out mainly in the UK, France, the USA, Belgium and those countries where it is actively used as a practical tool" (Mazuryk, 2015). Accordingly, in developing countries, the theoretical and praxeological foundations of social audit are only at the stage of active research and development.

Therefore, the scientific community continues to discuss the theoretical and methodological foundations of social audit in the context of assessing the social 
responsibility of business, competitiveness growth, ensuring social security, improving the efficiency of quality management and the like. This shows that the cognitive potential of social audit has not yet been definitively determined, but all researchers recognize that social audit is a necessary measure for making effective management decisions in the economy in conditions of uncertainty.

\section{Substantiation of theoretical and methodological foundations of social control in the field of economic management}

A more important scientific task is to substantiate the theoretical and methodological foundations of social control. This can only be achieved by clarifying the term "social control". Encyclopaedic publications contain various attributes of social control:

- essence: a way of self-regulation of the system (Sociological dictionary, 2008); a mechanism of system self-regulation (Sociology: Encyclopaedia, 2003); a system of forms and methods of influence (Psychological encyclopaedia, 2006); a complex of measures (Economic encyclopaedic dictionary, 2006);

- subject: society and social groups (Psychological encyclopaedia, 2006); state and public organizations, civil society institutions (Economic encyclopaedic dictionary, 2006);

- purpose: to ensure the functioning of the social system in accordance with the accepted standards, as well as to support socially acceptable patterns of behaviour (Sociology thesaurus, 2009); to regulate social behaviour in accordance with the standards established in the community (Psychological encyclopaedia, 2006); to ensure well-ordered interaction within the social system (society as a whole) and its individual subsystems and elements (individual social groups, organisations, etc.) in accordance with the country's established system of values, moral, and ethical, and legal norms, etc. (Economic encyclopaedic dictionary, 2006);

- form: observation (supervision) (Sociology thesaurus, 2009).

This analysis is incomplete, but its results indicate that the scope of social control is the social system, and the tool for self-regulation is normative (including legal) regulation. Accordingly, the subjects of such control are the institutions of civil society.

At the same time, we should agree with V. Palchenkova, who believes that "the social control category is a concept that has a much broader content compared to a purely legal understanding, since it covers a much wider range of means of influencing socially significant behaviour of a person, which include, in addition to legal means, those which are usually ignored by legal scholars when studying legal issues. In addition, the theory of social control demonstrates the life of social relations and the development of social patterns more fully than the traditional legal interpretation, because it includes the mutual influence of two contradictory planes - state and society" (Palchenkova, 2015).

Social control in the deviantological sense is considered as a mechanism for counteracting torts, designed to influence negative deviance and, above all, to prevent, reduce and transform the structure of delinquency (Mazuryk, 2011).

Now it is worth agreeing on the opinion that the social system is connected with the economic system, because one of the obligatory elements of two systems is a person, so the level of development of the social system depends on and affects the development of the economic system at the same time. In the economic system, a person is the producer of goods, works and services, and in the social system, a person is a consumer of goods, works and services. Accordingly, the perception of economic and social norms, as well as their observance, may have correlated reasons or those that have one source. Such interpenetration will affect the deviance and structure of delinquency in the economic sphere.

The social sphere as a system of social relations (including economic) is not a mechanical combination of its subsystems, but a specific combination of them (Economic encyclopaedic dictionary, 2006). It is essential for the study to realize that from the standpoint of economic sociology, the content of the economic sphere and the sphere of social relations reflects the characteristics of society that are most important for understanding the processes occurring at the "intersection" of economic and social manifestations of society. Based on the fact that social control extends to social relations, which closely intersect with economic, including management, relations, there are grounds for considering social control in the field of economic management as a type of economic management control. The formulated inference allows us to determine some aspects of the philosophical foundations of social control in the field of economic management.

Thus, the social sphere covers economic relations, which include those of them arising mainly at the micro level. Therefore, the latter are at the same time specific social relations that arise between individuals in the implementation of their own economic interests owing to the chosen economic behaviour. Accordingly, the exercise of public control is actualized when conducting business activities.

The ground for recognizing social control as a type of economic management control is that the economic system is a complex of subsystems, and elements, and a set of various forms of connections between them, the interaction of which results in laws on the development and functioning of this system, as well as the respective economic mechanism, which give it integrity and organisation, eliminate anomalies and enhance efficiency in order to achieve the common goal embodied in the 
basic economic law. The economic system can also be regarded as a set of all economic activities of people in the process of their interaction aimed at the production, exchange, distribution and consumption of goods and services, as well as the regulation of such activities for the purposes of the existing social formation. The main subsystems of the economic system are: productive forces; technical and economic relations; organizational and economic relations; economic property relations; economic mechanism. In analysing the composition of the main subsystems of the economic system, it can be noted that social relations and their producers (individuals, social groups) belong to virtually all of its subsystems (productive forces, organizational and economic relations, economic property relations), as well as economic mechanism, i.e. the national economy management system by using economic laws, resolving the contradictions of the social mode of production, sale of property, as well as human development and coordination of its interests with the interests of the team, class and society.

At present, it should also be borne in mind that, according to K. Marx, the social and economic formation is the unity of the interaction of the superstructure and the mode of production. However, for many post-Soviet countries, including Ukraine, the social and economic formation did not even come close to capitalist, because the ownership relations for the means of production were formed revolutionary in a mostly formally legitimate way, determined by political and legal institutions of society, which tried to consolidate production relations, that were in permanent transformation.

In the context of the study, it must also be taken into account that the content of the social mechanism of economic development and the individual social mechanisms of economic relations and economic processes is specified by economic consciousness and economic thinking, social and economic stereotypes, economic interests, economic activity, economic behaviour and economic culture.

Nowadays, social relations in the sphere of economic management, which are implemented in the economic behaviour of some individuals and social groups involved in economic management, act as a driving force, causing changes in the development of economic systems at the macro-, meso- and micro-levels.

In order to identify the real causes and the most profound incentives for people's economic behaviour, the category of economic interest is important as a form of relationship between economic entities regarding the production, distribution, exchange and consumption of limited material resources. It is economic interests that contribute to the coordinated interaction of different groups and social strata during the continuous adaptation to change. The patterns of the relationship of economic interests and the state of economic relations, manifested in economic interests in economic interests, acquire the character of the driving forces for social development, an incentive for people's economic activity. Economic interests and economic way of thinking are the preconditions for economic behaviour, which involves choosing the best economic alternative and making rational choices that minimize costs and maximize net income.

Representatives of social institutions, such as social group, labour collective, owner (founder), administration of the enterprise (non-economic entity), authorized state and local government body as well as public organization are subject to social control in the area of economic management.

The successful functioning of a social institution is connected with the existence of a comprehensive system of standards of behaviour for specific individuals in typical situations. These standards of behaviour are regulated, i.e. they are enshrined in the law and other social standards. Thus, the condition for social control in the field of management is the socio-economic norms of control, which should be understood as established rules of economic behavior and activities of people in employment with economic and non-economic entities (executive authorities, local governments). These standards are produced by social institutions and, depending on the level of application, are established at the state and municipal levels, as well as at the level of the individual participant in economic relations. Social control will not be possible without the existence of such standards, as there will be no compliance with the principle of comparativity, without which control turns into monitoring, only for the purpose of collecting information. It should be noted that all the economic standards mentioned in the study (Toshchenko, 2009) are at the same time social standards that should be followed in the field of economic management, since the social standards regulating social relations are also divided into economic standards (Modern legal encyclopaedia, 2009).

The results of social control in the field of economic management, in addition to compliance of economic behaviour with the established standards, should include: - deviant economic behaviour, i.e. economic activity that violates the social and economic standards of a particular social group (labour collective, administrative apparatus of the business entity, owners (founders) of the business entity, governing body of the noneconomic entity);

- delinquent economic behaviour, i.e. illegal economic activity of an individual manifested in his or her doings (actions, omissions), which are contrary to economic interests and cause harm both to business entities, their associations, non-economic entities, and to regional and national economy in general.

Analysis of the economic behaviour of the individual, in the context of the methodology of A. Smith, shows that two basic types of such behaviour clearly dominate in 
the formation of market relations: pre-market behaviour and market behaviour. Pre-market type of behaviour is characterized by the formula "guaranteed income with minimum labour costs”. Generally speaking, carriers of pre-market behaviour are characterized by market rejection or distrust, low self-esteem of the market economy, high level of social and psychological stress of the individual, who is influenced by social stereotypes formed during the Soviet economy era. The market type of behaviour is based on the principle of "maximum income with maximum labour costs”. It presupposes a high degree of economic activity of the individual, his or her understanding that the market provides opportunities to increase welfare in accordance with the efforts made, the knowledge invested, the skills applied. The market type of behaviour is formed in a small part of the economically active population of Ukraine and mostly depends on market reforms and their compliance with the social expectations of economically active individuals (Bardash, 2013).

There are now sufficient grounds to state that it is too early to identify the national economy of Ukraine as a market economy because "In the period of transition to a market economy, the state regulation of economic activity should contribute to the formation of selfregulating factors inherent in it, creating a legislative environment for a market society. However, in relation to the domestic economy of the early 90 s of the 20th century, this did not happen" (Economic encyclopaedic dictionary, 2005). This statement is based on the fact that, even today, in the national economy of Ukraine, the market as an institution does not perform the incentive, regulatory, monitoring and rehabilitation functions. At the same time, the national economy is experiencing dysfunctional market manifestations, including: the function of provoking and committing bankruptcy, antisocial, anti-environmental and payment-reducing function. The described state provides certain grounds for identification of the national economy as a "market fiasco", a term introduced by American economists E. Dolan and D. Lindsay (Economic encyclopaedic dictionary, 2005).

Thus, according to the described features of the national economy, the economic activity of certain business entities is under constant threat of suspension. This threat is formed by the dysfunction of the domestic economic model, which in turn forms a number of objectively significant and subjectively secondary factors that provide sufficient grounds for recognizing economic activity as risky because in the vast majority of cases managerial decisions are made in conditions of uncertainty (Bardash, 2013). The state of the business environment can be recognized as having a negative impact on the economic behaviour of individual actors in social and economic relations.

The inevitable costs of forming the labour market have led to the emergence of another type of economic behaviour - pseudo-market, which is based on the principle of "maximum income with minimum labour costs". The manifestations of such behaviour are corruption and economic crimes. One of the official indicators of the delinquent behaviour of actors in social and economic relations is the indicators of violations detected by state financial control authorities.

Thus, in 2010 alone, the Accounting Chamber of Ukraine and the State Audit Office of Ukraine jointly identified financial violations amounting to 87.1 billion UAH. These and other violations, the volume of which remains large today, indicate a certain discrepancy between the economic interests of individuals endowed with state power and the vast majority of Ukrainian citizens who have chosen the pro-European choice of the country's development (Bardash, Osadcha, 2020).

The existence of a pseudo-market type of behaviour in a particular social system indicates a low level of its development and the lack of a clearly defined concept of such development, which is characteristic to some extent for developing countries.

These data indirectly testify that a certain part of economically active individuals of Ukraine is characterized by a pseudo-market type of behaviour, transformation of which into a market type can be carried out, in particular, due to the implementation of public control in the sphere of economic management.

Summarizing the above, we note that social control in the sphere of economic management plays an important role, because it is an indispensable element of the social mechanism of development of economic systems at the micro-, meso- and macro-levels. Operation of microlevel economic systems or economic support systems for the functioning of non-economic entities should be subject to such control.

Social control in the sphere of economic management can be carried out in the form of social audit. At the same time, it may manifest itself through the tasks performed in the course of other forms of control in the sphere of economic management, the results of which should be used to provide economic and legal assessment or economic behaviour (actions) with assets affecting their quality, composition and volume, or economic behaviour (actions) which may manifest itself through managerial decisions to change the composition and volume of equity capital and liabilities of the business entity, the revenue and expenditure parts of the estimate of a non-economic entity.

The results of social control in the sphere of economic management make it possible to analyze the causes of differences in the economic interests of individuals, as well as small and large social groups and to determine the priorities of social and economic development. The formulated theoretical foundations of social control in the sphere of economic management will contribute to the scientific knowledge of control as a complex polymorphic phenomenon. 


\section{Conclusions}

The results of the study, in particular, the identification of the relationship between social and economic system, the fact of coverage of the social sphere of economic relations, the content of the social mechanism of economic development, have provided sufficient grounds for considering social control as a type of economic management control, which is implemented through a set of control actions aimed at determining compliance with social standards of economic behaviour of individuals or small social groups in the sphere of economic management. The object of such control is the social and economic relations that are implemented in the economic management system or the system of economic security management, and the subject is the compliance of the economic behaviour of an individual or social group to the established social and economic management standards. In this case, economic behaviour means a set of actions and activities that have occurred within the scope of economic competence or economic relations. The subjects of social control in the field of management should be considered endowed with control powers by representatives of social institutions that act as actors in economic relations.

In our opinion, social control in the field of management plays an important role because it is an indispensable element of the social mechanism of development of economic systems at the micro, meso and macro levels. Such control should be subject to the operation of micro-level economic systems or economic support systems for the functioning of non-economic entities.

Social control in the field of management can be carried out in the form of social audit. However, it may be manifested through the tasks to be performed in other forms of control in the field of management, the results of which should be provided economic and legal assessment or economic behavior (actions) with assets that affect their quality, composition and volume, or economic behavior (actions) that are manifested through management decisions to change the composition and amount of equity and liabilities of the entity, income and expenditure parts of the budget of the non-entity.

The results of social control in the field of management provide an opportunity to analyze the causes of differences in the economic interests of individuals, as well as small and large social groups and to determine the priorities of socio-economic development. The formulated theoretical foundations of social control in the field of management will contribute to the scientific knowledge of control as a complex polymorphic phenomenon.

\section{References:}

Akers, R. L. (2012). Criminological theories: Introduction and Evaluation. 2nd ed. Routledge, 258 p.

Aliev, F. A. (2008). Social audit in the context of social responsibility of large Russian corporations: extended abstract of Candidate of Economic Science: 08.00.05. Moskow.

Ahaverdiieva, Kh. F., Ivanisov, O. V., \& Lebedynska, O. S. (2019). Social audit in the theoretical field of social responsibility. BIZNESINFORM, vol. 5, pp. 157-161.

Bardash, S. V. (2013). Philosophical bases of social control in the sphere of economic management. Ekonomichnyy chasopys - XXI, vol. 5-6(1), pp. 85-88.

Bardash, S. V., \& Bardash, S. S. (2015). Reasons and content of improving the internal control paradigm. European Cooperation, vol. 5(5), pp. 35-46.

Bardash, S., \& Osadcha, T. (2020). Current Status of state financial control of Ukraine and ways of its improvement. Baltic Journal of Economic Studies, vol. 6, no. 2, pp. 17-24. doi: 10.30525/2256-0742/2020-6-2-17-24

Berger, P., \& Berger, B. (2004). Sociology: a biographical approach. Personality-oriented sociology. Moscow: Akademicheskiy Prospekt, $608 \mathrm{p}$.

Boislandelle, H. M., Esteve, J-M. (2007). Audit socio-economique d'un reseau local d'ent. Available at: http://www.globecsi.ru/Articles/2007/Boislandelle_Esteve.pdf

Chenash, V. S. (2016). Social audit as a tool to improve the effectiveness of quality management. Bulletin of Khmelnytskyi National University, no. 5, vol. 2, pp. 99-102.

Derii, V., Sachenko S., \& Babii, L. (2016). Social audit in the context of strengthening the requirements for corporate responsibility. Bukhhalterskyi oblik $i$ audyt, vol. 5, pp. 17-26.

Dolbnieva, D. V. (2014). The essence of social audit and its role in shaping the competitiveness of domestic enterprises. BIZNESINFORM, vol. 9, pp. 190-194.

Mochernyi, S. V. (ed.) (2005). Economic encyclopaedic dictionary / in 2 volumes. Vol. 1. Lviv: Svit, 616 p.

Mochernyi, S. V. (ed.) (2006). Economic encyclopaedic dictionary / in 2 volumes. Vol. 2. Lviv: Svit, 568 p.

Holinach, L. I. (2015). The essence of social audit in the process of establishing social responsibility of business. Ekonomichnyi analiz, vol. 18, no. 2, pp. 113-117.

Janowitz, M. (1975). Sociological theory and social control. American Journal of Sociology, vol. 81, no. 1, pp. 82-108. Levytskyi, V. V. (2012). Social control as a subsystem of management of social and economic stability of the enterprise. Innovatsiina ekonomika, vol. 6(32), pp. 65-67. 
Lehman, G. (2006). Reclaiming the public sphere: problems and prospects for corporate social and environmental accounting. Available at: http://www.sciencedirect.com/science/article/pii/S104523540190476919

Mazuryk, O. V. (2011). Social control: basic perspectives of conceptualization of social audit. Bulletin of Lviv University. Sociological series, vol. 5, pp. 169-177.

Mazuryk, O. V. (2014). Social audit as a modern diagnostic technology in the management practice of Ukraine: extended abstract of dissertation of Candidate of Social Science: 22.00.04. Taras Shevhcenko National University of Kyiv. Kyiv, 36 p.

Meier, R. (1982). Perspectives on the Concept of Social Control. Annual Review Sociology, vol. 8, pp. 35-55.

Modern legal encyclopaedia (2009) / [O. V. Zaichuk, O. L. Kopylenko, N. M. Onishchenko and others]; under general editorship of O. V. Zaichuk; Legislation Institute of the Verkhovna Rada of Ukraine. Kyiv: Yurinkom Inter, $384 \mathrm{p}$.

Mekheda, N., \& Madzhula, A. (2010). Social security planning at the enterprise. Bohdan Khmelnytsky National University of Cherkasy, vol. 1, p. 85.

Marushko, N. S., \& Volianyk, H. M. (2013). Social Audit as a Tool of Social Security. Lviv: Lviv Polytechnic National University Institutional Repository.

Mazuryk, O. V. (2015). Social audit as a modern diagnostic technology: theoretical and methodological principles of research, Western experience, domestic prospects. Bulletin of V.N. Karazin National University of Kharkiv, vol. 1148, pp. 107-113.

Palchenkova, V. M. (2015). Concept of social control in modern theoretical and legal science. Yurydychna nauka, vol. 8, pp. 7-14.

Psychological encyclopaedia (2006). Author-compiler O. M. Stepanov. Kyiv: Akademvydav, 424 p.

Ross, E. A. (1969). Social Control. A Survey of the Foundations Order. Cleveland - London, 416 p.

Sumner, C. (1994). The Sociology of Deviance. An Obituary. Buckingham: Open University Press, 381 p.

Spilnyk, S. I. (2012). Formal social control. Pravo ta derzhavne rehuliuvannia, vol. 3(8), pp. 173-177.

Toshchenko, Zh. T. (ed.) (2009). Sociology thesaurus. Thematic dictionary-reference book. Moscow: YUNITIDANA, $487 \mathrm{p}$.

Sociological dictionary (2008); resp. eds. H. V. Osipov, L. N. Moskvichov; Sci. Sec. O. Ye. Chernoschok. Moscow: Norma, $608 \mathrm{p}$.

Gritsanov, A. A., Abushenko, V. L., Yevelkin, G. M., Sokolova, G. N., \& Tereschenko, O. V. (ed.) (2003). Sociology: Encyclopaedia. Minsk: Knizhnyy Dom, 1312 p.

Yemelin, V. N., \& Skvortsova, Yu. N. (2013). Social audit as a method of increasing the efficiency of the enterprise. Molodyi vchenyi, vol. 7, pp. 161-163. 